\title{
Sciendo
}

\section{"The History of Human Stupidity": Vojtěch Frič and his Program of a Comparative Study of Religions}

\author{
MARKÉTA KŘíŽOVÁ \\ Center for Ibero-American Studies \\ Charles University, Prague, Czech Republic \\ marketa.krizova@ff.cuni.cz
}

\begin{abstract}
The present article represents a partial outcome of a larger project that focuses on the history of the beginnings of anthropology as an organized science at the end of the nineteenth and the beginning of the twentieth centuries, in the broader socio-political context of Central Europe. Attention is focused especially on the nationalist and social competitions that had an important impact upon intellectual developments, but in turn were influenced by the activities of scholars and their public activities. The case study of Vojtěch (Alberto) Frič, traveler and amateur anthropologist, who in the first two decades of the twentieth century presented to European scientific circles and the general public in the Czech Lands his magnanimous vision of the comparative study of religions, serves as a starting point for considerations concerning the general debates on the purpose, methods, and ethical dimensions of ethnology as these were resonating in Central European academia of the period under study.
\end{abstract}

KEY WORDS: Vojtěch (Alberto) Frič, Náprstek Museum, anthropology, comparative religious studies, history of anthropology

The present article deals with the beginnings of anthropology in the broad socio-political context of Central Europe. It aspires to reveal some of the multiplicity of interests and influences that helped to produce present-day "normal science", in the famous phrasing of 
Thomas Kuhn (KUHN 1962), and at the same time to assess the broader socio-political impact of anthropology, and its role in the complicated nationalist, political, economic and cultural competitions in this region.

As the nineteenth century neared its end, anthropology - established as a scientific discipline only few decades before - was undergoing a significant transformation. It developed mostly outside of traditional academic platforms, that is, universities. Instead, it took as its principal platforms museums, international congresses and newly founded journals. Shortly before 1900 the first chairs of anthropology appeared at universities. Publications as well as the numbers of practicing anthropologist multiplied, museums prospered and expanded and systematized their collections. However, the feeling of insecurity persisted, face to face with the established disciplines, such as Orientalist linguistics or classical archaeology, and at the same time an increasing awareness of the need to define the public role of anthropology, to ascertain its ability to contribute positively to the resolution of the pressing needs of contemporary society. The leading representatives of the discipline in Germany, France, Great Britain and the United States formulated and debated their separate, often conflicting visions of future development, in the form of articles, public lectures and polemics (STOCKING 1991; STOCKING 1985; VERMEULEN - ALVEREZ ROLDÁN 1995; PENNY 2002 etc.).

\section{The Náprstek Museum and its Role in the Beginnings of Czech Anthropology}

In contrast to this feverish development, for the Czech Lands ${ }^{2}$ it is difficult even to speak of "anthropology" in this period. But any discussion on this topic needs to be prefaced by a reminder of the intensifying competition of Czechs and Germans in various fields that had been taking place throughout the whole of the nineteenth century. Both groups tried to prove

1 The research for the present study was supported from the European Regional Development FundProject "Creativity and Adaptability as Conditions of the Success of Europe in an Interrelated World" (No. CZ.02.1.01/0.0/0.0/16_019/0000734) and the research program of Charles University PROGRES Q09 "History - The key to understanding the globalized world".

2 The Czech Lands, or the Lands of the Bohemian Crown, are the regions of Bohemia, Moravia and Silesia, historically ruled by the kings of Bohemia, from 1526 incorporated into the Hapsburg Monarchy. In 1918 they became - together with Slovakia and Carpathian Ruthenia - parts of the new Czechoslovak Republic. (PÁNEK - TŮMA 2009). 
they could qualify as fully-fledged and civilized nations. The strong German ethnic minority that from the 1880s had begun losing the upper hand in politics and economy in the Czech Lands struggled to prove its pertinence to the body of German culture and civilization. The Czechs, in turn, constantly compared themselves with Germans in all types of intellectual and cultural activity. There were however few detailed strategies for institutional or educational development and only minimum interaction with scientific endeavors going on beyond the border of the Czech Lands.

The physician Emil Holub in 1872-1879 and 1883-1887 undertook remarkable expeditions to southern Africa. But in spite of his name being praised throughout Europe and North America, and the grand exhibitions he mounted in Vienna (1891) and then in Prague (189293), and even though he gave lectures for such prestigious institutions as the Smithsonian Institution (1894), Holub in fact did not follow up with debates on academic forums, did not test or apply any theoretical approaches, and did not aspire to push scientific standards forward other than by amassing unique collections of African artifacts and specimens and accentuating the fact that these were deposited in Prague (ŠÁMAL 2013). Other Czech "anthropologists" were even more inclined to popularization and addressed primarily the domestic public in a patriotic vein (PƯTOVÁ 2013).

From the 1870s the Náprstek Museum (Náprstkovo muzeum), an institution of distinctive origin and history, constituted a center for knowledge about the lifestyles and cultures of nonEuropean nations for Czech intellectuals. In 1862, during the World Exhibition in London, a group of Czech patriots visited the city and later expressed their opinion that it would be beneficial to establish a technological museum in Prague. It was to be similar to that in Kensington (today the Science Museum), albeit "proportionate to our humbler means", and through documenting scientific and technological progress in the world assist Czech industrialists, at this period still marginalized by their German competitors, to develop their skills (MAJER 1994:16). The idea was taken over by Vojta Náprstek, owner of a prospering brewery and distillery, and his mother Anna. Vojta Náprstek, an open-minded person of broad horizons and education, enthusiastic for progress in both technical and social areas, significantly contributed to the development of Czech cultural and social life. With the support of his mother and later his wife Josefa, Náprstek promoted new ideas popular in the times, such as equal rights and access to education for women. (KLÁPŠŤOVÁ 2016:18-19). Anna Náprstková made a large bequest in her will with the explicit purpose of establishing the industrial museum, and it was opened in 1874 within the very premises of the brewery.

However, from the beginning the industrial collections were being supplemented by exotic souvenirs from all over the world, first those brought by Náprstek himself from his visit to 
North America in 1848-58, then by many other Czech travelers and tourists. Náprstek advocated the need to gain experience abroad in order to serve domestic needs, and at the same time the feverish nationalist competition at this period favored ventures to the furthest possible places to secure for the Czech nation "primacy" in their exploration. Náprstek therefore offered advice and financial support to travelers who reciprocated by sharing their adventures with the patriotic community and supplementing the museum with new objects. Many of the ethnographic artifacts were actually integrated into the collections as demonstrations of early developmental stages of various arts and crafts and as documentation of the progress which supposedly liberated Europeans, and especially women, from the bondage of exhaustive physical labor and freed their minds for intellectual pursuits. But as their numbers increased, the original conception of an industrial museum was seriously disturbed, being transformed into a rather hybrid institution, the more so because "primitive" artifacts from Bohemia and Moravia were also included in the expositions (such as embroideries and laces, under the denomination "Works of our Mothers") (SECKÁ 2011: 211-213).

What developed in this setting can, with a certain exaggeration, be termed the initial phase of Czech anthropology, even though parochial, restricted in scope, lacking theory and developed in a haphazard manner. In fact, the Náprstek Museum was more of a social club, a "salon" for well-to-do patriots, a place for social meetings and polite conversations in an exotic setting, than a platform for developing and précising scientific debates. When Vojta Náprstek died in 1894, the management of the museum was passed to a committee headed by his widow Josefa, who only received the lifelong usage of the inheritance, after which it was all to pass to the museum, and continue its existence as a museum of industry and applied arts. The exotic character of the collections was getting more pronounced, however. Also, there was a new competing institution, the "Czecho-Slavic Ethnographic Museum" that arose from the successful Czecho-Slavic Ethnographic Exposition of 1895. From 1901, the ethnographic collections were presented to the public in the palace in Kinský Garden in Prague. ${ }^{3}$ Josefa Náprstková resisted pressures for uniting the two institutions, but after her death in 1907 discussions concerning the future of the Náprstek Museum started again; the

Today, under the name Ethnographic Museum (Národopisné museum), they constitute part of the National Museum (FILIPOVÁ 2011). 
more so because of efforts, at this very moment, from part of the Czech patriotic elites for establishing a new Museum of Technology, founded officially in $1908 .^{4}$

\section{Vojtěch Frič - traveler, anthropologist, enfant terrible}

At this moment Vojtěch Frič entered the scene; adventurer and traveler, botanist and anthropologist, an autodidact who lacked formal education in either of the two disciplines, yet strove to excel in both, a complex and original personality. ${ }^{5}$ In 1907 Frič was in South America, in the middle of his third journey to this continent. Already during the first visit (1901-02 to Brazil), which he intended as a botanical expedition, he became interested in the culture of the natives, and on his second trip to Uruguay, Argentina and Paraguay (1903-05) he dedicated himself solely to ethnographic research, amassing numerous artifacts, pieces of costume, weapons and household utensils, which were exhibited at, and partly donated to, the Náprstek Museum. However, as he considered himself underrated in Prague, he established contacts with the ethnographic museum in Berlin, and donated the greater part of the collection to it in exchange for financial support that enabled his return to South America in 1906 (KANDERT 1983; BAĎUROVÁ 2012).

Of all those in the Czech Lands interested in non-European cultures, Frič was the only one who in the opening decades of the twentieth century took an active part in congresses and published in specialized journals approved by the academic community. He struggled to leave a mark, and to influence the state of anthropological theory of his times. His anthropological career was brief, as during and immediately after the World War I he became involved in politics and after the war returned to botany, disappointed by the fact that the international anthropological community refused to accept his theories and despised him personally, due to his eccentric behavior (PENNY 2003). In spite of this, the texts, activities, plans and opinions of Frič can be of great interest for historians of science in general, and anthropology in particular, as they show the reflection of scientific debates in the "margin"

4 For the history of the National Technical Museum (Národní technické museum, as the official name is nowadays), see HOZÁK 1997.

$5 \quad$ After returning from his first trip to Latin America, in public as well as private communication Frič doubled his first name with its hispanized variant so the version Alberto Vojtěch Frič often appears in bibliographic references. 
of European intellectual development and give testimony of how the theories were understood and opinions formulated.

While planning to write comprehensive groundbreaking works, Frič was never able to publish anything beyond articles (some of them published jointly with other anthropologists, such as FRIČ - RADIN 1906), mostly outcomes of his presentations at conferences. Even these apparently scholarly texts were often singularly inconsistent as to their content and form. There are also two volumes of essays and remembrances of various journeys, interspersed with ethnographic information, but without any reference apparatus; three adventure novels with strong autobiographical motifs and again containing information on the life and religions of the native peoples of South America; and an anthology of myths adapted for children. There is still however a rather extensive mass of unpublished material, letters received and copies of letters sent, outlines of public lectures, diaries and field notes. After his death in 1944, his widow Draga Fričová deposited part of his manuscript documentation in the Náprstek Museum and another part in the archive of the Institute of Ethnology and Folklore Studies of the then Czechoslovak Academy of Sciences; the rest remained in the family archive. In the 1950s, the Czech linguist and ethnographer Čestmír Loukotka transcribed and translated some of the documents from the Archive of the Academy of Sciences, but the proposed publication of the annotated edition was not realized, and moreover the originals were lost, so only the transcribed Czech version remains. ${ }^{6}$

Through the period 1902-1914 Frič pursued his anthropological study in feverish haste and his opinions developed rapidly. Lacking formal education above the standard Austrian high school-leaving exam (Abitur), Frič dedicated himself to self-study in the short interludes between his travels. There were several authors which he quoted extensively, but against whom he also argued (as the preserved correspondence shows, he directed long letters even to authors he did not know personally, in which he formulated his objections or asked for explication of concrete formulations). ${ }^{7}$ The disorganized style of his writing gives the

Nowadays the depositing institution bears the name of the Archive of the Institute for Ethnology of the Academy of Sciences of the Czech Republic (hereafter AEÚAV). See also information given by Yvonna Fričová in FRIČ - FERREIRA FRIČ 2012:84. Several of the notations of myths contained in this transcript were published in the English anthology of Chamacoco mythology (WOLBERT SIMONEAU 1987). This edition, however, is thus an English translation of a Czech translation (by Loukotka) of what apparently was a mixture of Czech, Spanish/Portuguese and native languages that Frič meant to process later, but never did.

7 For example, a letter to Charles de la Hitte of 3-IX-1905 (reflecting on his book La Teo-Cosmogonia. Base de la Filosofía Positivista. Explicada racionalmente según el Guaraní, Buenos Aires, 1899) 
impression that he was formulating ad hoc hypotheses that suited him at that moment. His grasp of theories and facts was also mostly intuitive, marked by an a priori opposition to established, "fossilized" opinions. Still, Frič had very concrete opinions of the task of anthropology and its methods, although these are overshadowed in his texts by numerous digressions and personal attacks on his opponents. At the turn of the nineteenth and twentieth centuries, armchair anthropology, more or less imitating the traditional Orientalism or Classical Studies (what Frič himself called "anthropology from the green table"), still predominated over all other methods of researching non-European cultures. Frič persistently called for field research - instead of mere collecting trips to furnish museum collections and insisted that anthropologists interpreted the artifacts through the cultural context, and knowledge of native languages. ${ }^{8}$

Frič was an ardent protagonist of "positive science", non-speculative and provable, based upon factual evidence and untainted by ideology. Entering fully into the modernist intellectual position of a researcher detached from the world and bringing order into a chaotic reality, and of nature and society waiting for the scientist to reveal their hidden truths, Frič was convinced that "positive truth" existed, revealing itself to those able to throw away the traditional worldview and adopt a critical posture towards the world (HODAČ 2009:93-95). As was the case with his other inspirations, he imbibed the principles of positivism intuitively and through unsystematic, fragmented readings, and probably never knew - and certainly never quoted - the work of Auguste Comte. However, precisely at the turn of the nineteenth and twentieth centuries, positivism framed the debates on human and social sciences in various Latin American countries, within the frame of the sharp conflicts between Catholics, anti-clericals and governmental agents striving to assert their authority over schools and intellectual development in general, as well as public spaces and national symbols. It was

and several letters to the religionist Ernst Siecke, all in the documentation transcribed and translated by Loukotka, AEÚAV, Ms. 445, ff. 201-410, 422-447.

$8 \quad$ However, Frič's own linguistic capacities had been doubted by his opponents. When in 1907-1908 he became involved in a fierce conflict in Brazil over the alleged massacres of native populations by German colonists, his poor knowledge of native languages was often mentioned by his opponents. (See for example the record of the discussion during the $16^{\text {th }}$ Congress of Americanists in Vienna [1908], in HEGER 1910:Ixii.) In fact, Frič himself revealed in his diaries, notes and other materials not destined for publication that he did not have command of the native languages, that he communicated with his respondents through interpreters, and that many of his notes did not come from the "savage" tribes of the interior, but from natives he met at random during his stays in Argentinian and Brazilian cities. See the materials in AEÚAV, Ms. 445: Frič admits that he doesn't speak the Kadiuweo language (f. 112); "I understand badly the language of the Tumraha" (f. 221) etc. 
hoped that instead of the representatives of the church it would be scientists who would take up new roles in crafting economic, legal, and political policy, both nationally and regionally. In short, in Latin America secularization was perceived as a prerequisite of modernity, and this was also the position of Frič, who probably found inspiration in these debates during his early journeys and later applied them also to the debates in the domestic context (ARDAO 1963; RODRIGUEZ 2013) ${ }^{9}$.

In fact, in the Czech Lands too these issues were publicly discussed. The Czech nationalist movement was marked by a sharp critique of Catholicism, taking as its main topic the Hussite period, the fifteenth century revolt against Catholicism, and connected the renewed Catholic pressure with the taking up of the Czech throne by the Habsburgs. But in contrast to Latin America, radical secularization was never an issue in the Czech Lands (NEŠPOR et al. 2010; BALÍK et al. 2016). Frič himself, however, was an avowed atheist, a member of the Czech branch of the "Free Thought" association, whose ultimate objective was a complete liberation of public life, state and education from confessional influences. ${ }^{10}$ While ostentatiously posing as a scientist untouched by the clichés of the times, however, Frič also imbibed thevocabulary of Czech nationalism, based upon anti-Jesuit diatribes. In the popular imagery, Jesuits were presented as the initiators of the intellectual and cultural decline of the Czech nation and the embodiment of obscurantism. For Frič, "Jesuit" was a synonym for "dim-witted". ${ }^{11}$ However, he insisted that the Czechs should prove their feeling for their nation by raising it

Frič also expected such development, see his letter to Theodor Bartošek, Patagones, 1-III-1908, ANpM, fund Frič 12/40.

10 The association of Free Thought was founded in Brussels under the patronage of Charles Bradlaugh in 1880, as the "Federation Internationale des Societes de Libre Pensée". From 1887 international congresses were held in various European cities and later also outside the continent, usually biannually, and there was an Executive Committee to organize them. But mostly, the national branches acted separately (for the Czech branch, see KUDLÁČ 2005).

11 For example, in an article dealing with his archeological excavations of the shell heaps (Sambaquis) on the Brazilian coast he laughed at the idea, expressed by some "educated Brazilians", that the origins of the heaps were in the time before the Flood and the skeletons excavated "from the sinners of Noah's time". "It is for them dogma, in which man should believe without thinking. I suppose this opinion comes from the time of the Jesuits" (FRIČ 1907a:118). When describing some native ceremony, he tried to depict the atmosphere: "It was already after sunset, the path was slippery and everywhere darkness as in the brain of the Jesuit" (Unpublished manuscript "Slavnost mrtvých" [Feast of the Dead], undated, translation from German by Loukotka, AEÚAV, Ms. 445, f. 41). 
intellectually and learning from the outside world, not by enclosing themselves in a feeling of their own exclusiveness.

Besides positivism, Frič came under the important influence of the evolutionary schemes of Lewis Henry Morgan and Charles Darwin, whose contributions to the development of science he considered groundbreaking, as they undermined the existing Biblical (that is, for Frič, falsified) theories of the origins of man and society. They embodied for Frič "Science", silenced and marginalized; and he labeled those who refused to accept the opinions of Morgan and Darwin as "reactionaries" (FRIČ 1977:27). He also extensively quoted Edward Burnett Tylor (1871), even though he interpreted him in an original way, reducing Tylor's evolutionary scheme to the dichotomy savagery/civilization. Also, while Frič accepted the vision of the progressive development of human societies towards increasing complexity and technological expansion, he did not interpret such development as bringing a favorable change of lifestyle conditions. Even though his highest praise was formodern society, able to make use of the accumulation of scientific knowledge and overcoming the ignorance and superstition of primitive times, as this ideal had not yet been achieved, he gave preference to the "savage" stage. In fact, his understanding of evolution was rather similar to that of the early missionaries, who interpreted human development as the progressive ruin of primitive simplicity.

At the same time Frič refused to accept the basis of evolutionist thought, namely, the idea of the inherent sameness of the human psyche. Therefore, in his study of religions, he also sharply opposed Adolf Bastian and his theory of "elementary ideas" - that all humans share a certain set of basic, fundamental ideas or experiences and there is no profound and unbridgeable difference between "primitive" and "modern" or "religious" and "scientific" humans. Religious diversity was, according to Bastian, to be examined not for the "surface variation" but for the deeper and more universal patterns and truths that were expressed in them. ${ }^{12}$ Frič was convinced of the important influence of the natural environment upon human societies, especially of what he called "wilderness" (divočina) -untamed nature upon savages or "wild people" (divoši) (HODAČ 2009:81-82). In this, he was in fact approaching the opinions formulated at about the same time by Lucien Lévy-Bruhl, who was convinced that the thoughts and beliefs of "primitive" people came from a completely

12 See among others BASTIAN 1892, also FISCHER - BOLZ - KAMEL 2007. For Frič's opinion on Bastian see e.g. his introduction to a never-realized treatise on the study of comparative mythology, AEÚAV, Ms. 445, f. 386 
different way of thinking from that of modern people, the "pre-logical mentality" (LÉVYBRUHL 1926) ${ }^{13}$.

In a way, Frič also anticipated the theories of ecological anthropology, considering cultural evolution to be in an important way dictated by adaptation to the natural environment, but at the same time he accentuated the moral dimension of this adaptation, ascribing to the influence of the "wilderness" the aptitude of the "wild people" for freedom, simplicity, honor, and love for one's neighbor, while he associated the departure from wilderness - that is, the advent of sedentarization, intensive agriculture and the beginning of the cultivation of the wilderness -with the beginning of the progressive decay of these characteristics. As early as during his first voyage to South America, Frič arrived at the conviction that the majority of the indigenous population was destined to perish, and therefore devoted himself to their study, and to salvaging their knowledge for the benefit of mankind. For, as he wrote, "not everything in the wilderness is beautiful and perfect; life there is a grand combat of dark forces, in which those who are ready, brutal and direct always win. But I am convinced that we can find much instruction for ourselves among the people who walk with a naked body but modestly covered soul." 14

\section{Study of mythology}

All of these principles also manifested themselves in Frič's posture towards the study of religions of the "savages". While his early texts displayed interest in all aspects of native cultures (FRIC 1906a), he rapidly focused his attention in this direction. It seems that the turning point had been his participation in the $37^{\text {th }}$ meeting of the German Anthropological Society in 1906 in Görlitz, the first scientific forum he took part in after returning from his second journey.

13 This theory had been criticized by Edward Evans-Pritchard, Bronislaw Malinowski and eventually by Lévy-Bruhl himself (SALAZAR 2015:7).

14 Nots to a public lecture of 1908, transcription of document from a family archive in FRIČ FERREIRA FRIČ 2012:88. 
Frič presented a lecture on "myths and human migrations in South America" (FRIČ 1906b) and on the basis of the subsequent discussion arrived at a conviction that the whole existing concept of anthropological study of religion was wrong. It is interesting that in this period other European anthropologists too were beginning to think over and discuss the future of religious studies. Traditionally, the study of religion often equaled Biblical studies and theology, or, at most, was realized within Orientalist departments. At the turn of the nineteenth and twentieth centuries, however, anthropologists begun drawing attention to nonEuropean spiritual traditions, at the same time legitimizing their being considered as "religions" and taken seriously, and viewing them dispassionately, scientifically and in their proper context, in order to clarify some of the general problems in the study of the human character. Such study added legitimacy to the general program of the anthropological study of non-European cultures.

It is not certain how much Frič was aware of these developments, but he considered the study of mythology more absolutely crucial to historical and anthropological research, more objective and revealing for the earliest history of mankind than the study of linguistics or archaeological excavations. Again, there was a rather restricted number of authors which Frič quoted repeatedly - alongside Tylor, Leo Frobenius and Paul Ehrenreich; apparently, he did not know Frazer or other important theoreticians of religion of his time. Ehrenreich especially he found inspiring, as his theories made it possible for Frič to combine evolutionary approach with diffusionism. In spite of being critical of Ehrenreich's methods (that is, the inadequacy of his field research, FRIČ 1918: 77), he concurred with him in seeing the myths as the heritage of the primitive unity of mankind. Ehrenreich formulated, on the basis of his research of mythology in Matto Grosso and other parts of South America, a theory of the origin of all mythologies at the dawn of mankind, during the phase of development Ehrenreich denominated Homo alulus. (EHRENREICH 1905). Frič speculated that these original mythologies had later been adapted to concrete climates and ecosystems. 
However, in contrast to many other protagonists of diffusionism, Frič opposed sharply the idea that the interchange of mythological motives took place along the other cultural diffusion. Instead, he was convinced that each "nation" or "tribe" guarded and protected its myths, so that the spreading of myths marked the migrations of ethnic groups. "We can follow, through myths and legends, the prehistoric migrations with the same certainty as the woodsman reads in the footprints on a prairie. Where archaeology stops speaking to us, the science of comparative religious studies begins" (FRIČ 1912c:149). He was therefore convinced that the study of mythology can help to clarify the oldest phases of the history of mankind, including the problem of the origin of American natives, and their migrations before the European conquest. Frič also asserted that the only cases of myth interchange happened when biological merging of the groups occurred, so that "a mixture of myths means a mixture of blood" (FRIČ 1906b: 147) ${ }^{15}$.

Frič was convinced that he would prove the veracity of his hypotheses if there existed "a precise classification of myths, not only of the whole mythological complexes, but the motives and specific details. Ehrenreich and Boas warn against the comparison of individual parts taken out of context, but I consider this to be highly important and useful. [...] There are many such parallels and because one thought is expressed by the same words, such details are more important than complete analogies in the whole myths. Such completely identical ideas could not have developed spontaneously in various parts of the world, and thus I am forced to think either in the mutual affiliation of both nations or interchange." 16 Apparently, Frič was not aware of the efforts of Antti Aarne, who published his first version of his catalogue in $1910,{ }^{17}$ but his independent endeavor proves that the anthropological community in Europe essentially headed in a similar direction.

15 In the already quoted introduction to the never finished comprehensive volume on the study of mythology, he repeated: "The Brazilian Indians have as much European or African blood in their veins as many Indo-Europeans, and we find African motifs in their mythology" ("Příspěvky k dějinám náboženství a mytologie jihoamerických kmenů", AEÚAV, Ms. 445, f. 378).

$16 \quad$ Ibid, f. 377.

17 The American folklorist Stith Thompson translated Aarne's motif-based classification system in 1928, enlarging its scope; but only Thompson's second revision created the "AT number system" (also referred to as "AaTh system"), used until today (AARNE - THOMPSON 1961; also HANSEN 1997). 
In view of repeated instigations for using precise terminology in the comparative study of religions, Frič's own definition of the very object of his studies - religion - might seem intuitive. However, it was in accordance with his general attitude to anthropological study and science in general. "I understand under [religion] an aggregate of faith in God, that is, faith in what we cannot prove, and service to that God." 18 Again the centrality of the concept of "truth" appears here, or rather "scientific truth", truth based on proper application of scientific method for Frič, while theories unsupported by factual evidence were for him nothing more than "beliefs", that is, "superstitions". This understanding of "truth" as a product of rational endeavor was precisely the reason why Frič, even though he considered the erasure of the positive influences of the wilderness via the evolution of arts and crafts to be a cause of the general moral decline of mankind, still considered (western) European civilization, or rather, those constituent parts of it that accepted positivist ideas, to occupy the highest rung of the ladder on the evolutionary scale. He saw a central instigation for movement on the evolutionary scale from primitive to rationalist society as a twist from passive act of faith to active search for knowledge. In this he agreed with other representatives of Free Thought, among them Theodor Bartošek: "The organization of Free Thought aims at beginning the third developmental stage of mankind. The child and the savage are playful. Only on a higher scale man comes to work. But there is one more scale to surmount, and transform man into a being capable of thought." (BARTOŠEK 1914:11).

\section{Museum of Religions}

At the same time, Frič's positivist ideals were an important influence on the way he approached the study of religions. For Frič, myth was a product of the imagination of men on the lower rungs of the developmental scale, unable to understand the laws of nature surrounding them, as revealed by the title of another unfinished manuscript that Frič entitled "The comparative study of human stupidity (Contribution to the comparative history of religions of South American natives)". He was convinced that "the more ignorant a man is, the greater his fantasy. [...] The further we go back into the history of the human mind, the greater fantasy we find, so we can suppose that primitive man had an enormously developed fantasy. 
It was one of his first characteristics, giving him the illusion that he understood all the mysteries of nature, the origin of sun, moon, stars, storms etc. That is the origin of myths and also the proper interpretation of the word "myth": not only the fantastic explication of natural phenomena, but also naïve and stupid explications that uneducated, primitive man elaborated through his fantasy. [...] These products of his stupidity (we should not be afraid to use proper words) often until today constitute the basis of our worldview and our philosophy that we defend stubbornly. But the laws of nature are stronger than this bad human fantasy." 19

In another text he conceded at least some sense to mythologies, both in the sense of being a "poetic" genre and because "the fundamental wisdom of mankind had been preserved for us in the mythologies of various nations, the story about the flood and the sun hero". ${ }^{20}$ Still, unlike Tylor and Frazer, Frič did not approach religions and mythologies as just interesting academic topics, but as something menacing modern society that needed to be understood and then uprooted. He opposed even the genre of fairy tales - in his understanding, vulgarized myths whose true content was forgotten by subsequent generations. "The fairy tales we narrate to children [and other] opinions of our savage forefathers are what delays all progress of mankind, the greatest enemy of positive science. On these are based all tyrannies and slavery, to those we owe all wars" (FRIČ 1912c:153). In another text, he warned: "Our worldview is not up to today based on positive science, but on the opinions of wild, barbarian or half-civilized peoples and their mythology." ${ }^{21}$ This was also why, after the death of Josefa Náprstková, Frič maintained persistent correspondence with the committee, offering proposals for the substantial reconfiguration of the Náprstek Museum. Frič never ranked the Náprstek Museum, the "distillery", as he called it, ${ }^{22}$ highly. He considered it a hopelessly backward, retrograde institution. He proposed to transform the "warehouse" into an institution with a plan, mission and purpose - namely, a "Museum of Religions" that would serve not only as a repository of artefacts for the use of scientists, but also for educating the

19 "Srovnávací studie o lidské hlouposti (Příspěvek k srovnávacím dějinám náboženství jihoamerických domorodců)" (undated), translation from German by Loukotka, AEÚAV, Ms. 445, f. 393-395.

20 Manuscript "Přednáška o mé cestě do Chaka, 1908" [Lecture about my journey to Chaco], 1908, given to Czech journalists in Prague in 1909, ed. in FRIČ - FERREIRA FRIČ 2012:85.

21 “Srovnávací studie o lidské hlouposti”, AEÚAV, Ms. 445, f. 395-396.

22 Letter from Frič to an unidentified member of the "Free Thought" organization, Patagones, 15-V1908, ANpM, fund Frič, 3/2, unpag. 
public in the basics of the Positivist worldview. ${ }^{23}$ When the committee of the Náprstek Museum ignored Frič's proposal, he established what he denominated a "Museum of Religions" in his own house.

The Náprstek Museum certainly resembled a "warehouse", as the displays were not arranged according to a premeditated plan. There was the basic evolutionist principle that stood at the very founding of the original Industrial Museum (primitive vs. modern technologies), but became overshadowed by chaos, also because the museum lacked any qualified curators. However, the same resemblance to a chaotic warehouse could be seen in the most prominent German anthropological museums of the period, something Frič was well aware of. The early protagonists of anthropology attempted to create knowledge about humanity free from what many anthropologists perceived to be the weakness of Classical studies: subjectivity, selectivity, and narrative. The Museum für Völkerkunde founded in 1886 by Adolf Bastian in Berlin, that later served as a model to various other institutions, also conformed to this plan. ${ }^{24}$ Bastian insisted that the exhibits were to be presented without resorting to what he thought to be a fictitious narrative structure of history. No particular object, grouping, or arrangement was supposed to stand out or be emphasized. There was no developmental series of artifacts, and the museum's goal was not explicitly pedagogical, it was to serve the elected few of the scientific community. However, the resulting effect was what Glen Penny in his analysis described as an "overwhelming mass of artifacts, torn out of their original contexts". Heated debates took place about the very nature and purpose of such collecting and display (PENNY 2007:52; also PENNY 2002).

23 Letter from Frič to Ludvík Kottner, Patagonas, 15-V-1908, ANpM, fund Náprstek, box 101/81. In an article in which he described his visit at the British Museum in London, Frič also condemned "our museums [...] amassing things that don't belong there, only tearing apart collections and piling one thing upon the other", where "there is no place, no science possible" (FRIČ 1912d:254).

24 The Berlin museum was not the oldest anthropological museum in Europe - the primacy was gained by Basel, where anthropological museum was inaugurated in 1849, followed by Leipzig, Hamburg, Bern and Vienna. However, the Berlin museum was by far the most influential, its concept being imitated also by the earlier institutions (GINGRICH 2017:36). 
Frič commented negatively on the museological ideas of Bastian in the first place because he saw in him "the omnipotent director", the embodiment of established, hierarchized, petrified science - convinced that his theories were respected only because of Bastian's official standing. ${ }^{25}$ But more importantly, Frič perceived the necessity of identifying for every individual exhibit the reality within which the item was used and trying to understand how the material culture was linked with the religious beliefs of those who made them (BAĎUROVÁ 2012:15). Only when supplemented with information gained through field research from those who made and used the objects could these be used for scientific research. Also, Frič sharply opposed what he considered "that wrong starting point of ethnographical studies - that every artifact is based on superstition". ${ }^{26}$ Repeatedly he pointed out that the anthropologists often wrongly identified objects as "idols" or "amulets" that in fact served secular purposes. "Now that I understood better the so-called religious ideas of the Indians, I can point out how carelessly we identify the objects, whose true meaning we don't know, and how archaeological studies especially are tainted with fantasy. Often it happens that we label as idols or votive objects some artifacts that we simply do not recognize. [...] Many wooden, stone and wax figurines I got from the Indians were either decorations or toys, and to term them idols is just as wrong as to label the rubber cow I played with as a child with this word." (FRIČ 1913:401).

There was another important idea behind Frič's vision of the Museum of Religions. As an avowed atheist, he was determined to put anthropology at the service of the "enlightening" of the general populace, thus accelerating the process of change from simple to complex, from irrational to rational, and from superstition to enlightenment. He considered precisely the comparative study of religions to be "one of the most important social sciences" because it could be used for anti-confessional propaganda.

25 "Today the theory is completely invalidated - Bastian is dead - he is no more the director of the museum - and not even the German science believes in the dogma of the identical character of human psyche" (FRIČ 1912c:158).

26 Letter from Frič to Ludvík Kottner, Patagonas, 15-V-1908, ANpM, fund Náprstek, 101/81.

DOI: 10.2478/eas-2018-0009 C University of SS. Cyril and Methodius in Trnava. All rights reserved. 
Of course, social and cultural anthropology established itself purposefully in the second half of the nineteenth century, as the science whose aim was to assess objectively, rationally, and unemotionally the irrationality of non-European cultures, their savage practices, superstitions and wrong worldviews. Edward B. Tylor had already expressed the belief that science would ultimately destroy religion by showing people the irrationality of their myths and rituals and by improving their lives. Still, Tylor admitted that the myths and rituals of "primate peoples" were "often to a high degree intelligible and rational in their origin, consistent and regular in their structure, [...] rational enough from the savage point of view, though apt to seem farfetched absurdities to moderns in their much changed intellectual condition." (TYLOR 1871, 2: 1-2, 40).However, the ultimate goal for Frič was not to reveal the inner logic of religious thought (as was the aim of his contemporary Rudolf Otto), but to educate the public about atheism. "The comparison of various religions teaches people to find out the mistakes of their own, inherited or inoculated beliefs, and more, teaches them to think about the things they would before not dare to think, and instigates them to think in general. [...] The more we compare various religions, the better we can see that they are almost identical in their origin" (FRIČ 1912c:157-158). And, in another text: "The study of mythology can prove how naïve and stupid our wild ancestors have been and what stupidities they believed that had cost so much blood. Through such examples we might change a bit the opinions of present-day or future generations." 27

This would also make use of the absurd mixture of artefacts in the Náprstek Museum, as the displays of non-European cultures could be complemented by those of Central Europe,

27 "Srovnávací studie o lidské hlouposti (Příspěvek k srovnávacím dějinám náboženství jihoamerických domorodců)", undated, translation from German by Loukotka, AEÚAV, Ms. 445, f. 396. In the same text, Frič also offered the comparative study of mythologies in the service of the Czech nationalist cause. "For example how useful it would be to us Slavs to discover, on the basis of mythological or linguistic studies, the falseness of pseudo-history, namely, that the highly praised German culture that is being exported to the whole world and forced even upon the Africans is nothing else but Slavic culture, after the migrating hordes of Germans attacked the peace-loving, agricultural Slavs that occupied a higher cultural level, and from them learned their mythology and their science and many cultural achievements, such as the plough, honey, beer etc." (f. 397). 
influenced by popular religiosity, depriving Catholicism of its label of the most developed religion of all. ${ }^{28}$

Frič sharply opposed the missionaries and their activities among the natives, as well as occultists and spiritualists, at the period under study popular all over Europe. ${ }^{29}$ In 1906 he took an active part in the international congress of Free Thought in Buenos Aires, presenting a sharp critique of missionary endeavors among the "savage" peoples of South America, as these hindered their evolution. "Every penny given to the missionaries contributes to the fooling and cheating of uncivilized nations that would need a lot of money to step forward to be our equals" (FRIČ 1907b:130). ${ }^{30}$ But he also opposed the "cheating" practices of native healers and shamans. He was convinced that "the priests and sorcerers rarely believe in what they teach others". ${ }^{31}$ And more, he was convinced that the "savages", on the eve of evolution untainted even by "superstition", only fell to religious confusion because of unscrupulous sorcerers, who via prophecies, dreams and hypnosis exerted their authority over the people by implanting in their minds the fear from the supernatural. "The sole purpose of religious ceremonies is to increase the trust of the people [in sorcerers]" (FRIČ 1913:400). ${ }^{32}$ Left alone, Hloucha, Frič offered themes for a proposed journal - that was apparently never put into practice - on enlightening themes, among them "Fairy tales of the Indians in Matto Gross and of the Slavs", but also "Comparison of our priests and the Indian sorcerers" (Letter of Frič to Joe Hloucha, Matto Grosso, 16-II-1905, ANpM, fund Frič, 3/2, copy).

Frič admitted that in his youth he was much intrigued by the theosophy and spiritualism. "Therefore, I have had enough experience with empty ceremonies" (FRIČ 1977:73-74).

30 The original text of the lecture was not preserved, only the subsequently published Czech version (FRIČ 1907b). On this congress, DE LUCIA 1999, Frič's presentation mentioned on p. 191.

31 "Přednáška o mé cestě do Chaka, 1908" in FRIČ - FERREIRA FRIČ 2012:67-68.

32 Also, he was convinced that the earliest phase of human development was that of democracy and equality, and despotism was established only later, thanks to the activities of the priests (FRIČ 1906b:147-148). In a letter to Argentinian scholar Charles de La Hitte of 1905, Frič asserted: "There exists brotherly equality among these Indian tribes. Somewhere they have hereditary chiefs, but without much influence. They have chiefs of songs and poetry (Bororo). It is a government of arts, of science, of education. They are chiefs in war that gain recognition through bravery or diplomatic capacities. That is the golden age that also existed among the ancient Slavs. [...] Progress is when children can draw upon the experiences of their fathers, because the life of the individual is unimaginable without the work and experience of the forefathers. But these bases also bring with them various religious dogmas, certain gods that men cannot get rid of and from which theocracy arises that makes possible for individuals to dominate other people, because every philosophy is powerless against human ambitions" (translation from Spanish by Loukotka, AEÚAV, Ms. 445, f. 423). 
the savages would slowly work out the laws of nature for themselves and reach the stage of positive science, instead of plunging deeper and deeper into the darkness of superstition.

Frič himself lacked any respect for religious taboos and restrictions, even though outwardly he conformed to them when necessary. He considered religious rituals devoid of any deeper cultural meaning and to be nothing more than redundant procedures. His role as a researcher was to isolate the objective truth out of these "nonsenses", not to search for their inner logic, albeit different from the logic of European atheist. During his second journey, in 1904, he described vividly in a letter to Josefa Náprstková how he enriched his collection of artifacts by plundering a native cemetery, even though he was explicitly forbidden by the village elders to enter the site. He even prided himself for demonstrating to the villagers the meaninglessness of restrictions based upon superstition. ${ }^{33}$

It is interesting that the Free Thought movement in general ignored the museum as a possible vehicle for educating the population. French, English, German and also Czech "free thinkers" used especially printed materials, journals, brochures and books for propagation of their opinions, and also public lectures and discussions, even though at the same time professional museologists (archaeologists, anthropologists etc.) had been presenting their institutions as crucial in developing worldviews and asserting accepted knowledge about reality. Throughout the nineteenth century museums were purposefully constructed as "temples of science", repositories of knowledge, dedicated to the dissemination of learning and to advocating understanding, tolerance, and the dissipation of ignorance and superstition, where the artifacts of one time and one culture can be seen next to those of other times and other cultures without prejudice (DUNCAN 1995; CUNO 2008, MINUCCIANI 2013). ${ }^{34}$ Within this context, it is surprising that the potential of museums was ignored by the protagonists of anti-religious propaganda.

33 Letter from Frič to Josefa Náprstková, Gran Chaco, 5-VIII-1904, ANpM, Scrapbook 73 "Vojtěch Frič", f. 97.

34 In his text about the British Museum Frič also celebrated it as a "temple of science" (FRIČ 1912d:254). 
Frič believed that the anthropological museum was to function on two levels, not only as an exclusive scientific site for the selected few, but also as a public place that had to address society at large and upon which the public should have influence. In the same letter in which he demanded the transformation of the Náprstek Museum into a "museum of religions", Frič contradicted what the addressee of the letter - chairman of the curatorial committee apparently wrote to him previously, namely, that the organization of the museum was "not his business". "There are in the museum collections that I donated, and therefore I have right to express my opinion. And even if you would try to deprive me of this right, Náprstek made his museum a gift to the nation in his will, and so the public has the right to judge the activities of the committee." 35

It seems that Frič's interest in the potential of the museum as a vehicle for the development of science and of education was of a long-term nature. On a postcard with a depiction of the Grassi Museum addressed to Josefa Náprstková from Leipzig, Frič wrote: "What I would give if you could see these museums and their arrangement. Even though they have exhibits from many fewer places than we do, they surpass us in scientific arrangement and work." 36 He referred to the same problem of the "arrangement" of the museum collections in a letter of 1913, in which he again outlined the project for a Museum of Religions. In this letter, Frič stressed that his planned way of presenting his "new, unknown, scientific material" is completely novel, making it possible for the visitor to grasp from the exhibition the totality of the mythological worldview of the South American natives. "When this new system of museum exhibitions is implemented universally, it will start a new phase in human thought, as only what we educated know will be clearly and comprehensibly presented to the public through it."37

35 Letter from Frič to Ludvík Kottner, Patagonas, 15-V-1908, ANpM, fund Náprstek, box 101/81.

$36 \quad$ ANpM, Scrapbook 73 "Vojtěch Frič", f. 295. The postcard is undated, but it must have been sent before September 1907, when Náprstková died.

37 Letter from Frič to an unknown recipient (addressed as "Herr Consul") of 17-VII-1913, ANpM, fund Frič, $3 / 3$ (copy). 
In the first decade of the twentieth century, the idea to establish a museum dedicated exclusively to the comparative study of religions was way ahead of the times. There was the Musée Guimet, founded in 1879 in Lyon and later transferred to Paris, which combined the approach of the history of religions and history of art; but this institution was run along the traditional lines of Oriental Studies (REY et al. 2001). There was also the "Loan Collection of Objects used in Worship" opened in 1892 within the Museum of Archaeology of the University of Pennsylvania to document "the evidences of the unity of the human race to be found in the various religions" and also to offer to the public objects privately owned, "whose possessors were unaware of their significance and value" (anon. 1892:225). But this collection also focused mainly on the Orient. In Europe such a Museum of Religions proper was established only two decades after Frič formulated his proposal: the "Religionskundliche Sammlung" within the Philipps University in Marburg, Germany, opened in 1927 thanks to Rudolf Otto (BRÄUNLEIN 2005). And, finally, there was the State Museum of the History of Religions in Leningrad/St. Petersburg, founded purposefully as an anti-religious institution in 1932 (to become in 1954 the Museum of the History of Religion and Atheism), whose objectives were very similar to those of Frič, that is, the education of the masses in the principles of atheism.

\section{Conclusion}

In contrast to his Soviet counterparts, Frič did not succeed in carrying through his vision of a Museum of Religions. Neither did he enforce his way of approaching the study of nonEuropean cultures in the local context of the Czech Lands or at international anthropological forums. As with many other projects, he abandoned these efforts quickly and focused on other debates and clashes. The Náprstek Museum existed as a private institution even after the establishment of the Czechoslovak Republic in 1918. Not until 1932, when the committee was unable to manage the collections and maintain the museum building, was it put under the control of the Czechoslovak state under the name "Náprstek Museum of General Ethnography" (Náprstkovo museum všeobecného národopisu) In 1949 it was incorporated into the National Museum (SECKÁ 2011:264); the industrial displays were transferred to the National Technical Museum and the Bohemian and Moravian exhibits to the Ethnographic Museum. Thus at least part of Frič's vision of its reconstruction became true. The heterogeneous "warehouse" was transformed into museum of anthropology. 
Karl von der Steinen, contemporary of Frič and famous German specialist in the cultures of Amazonia, was convinced that the task of ethnology was to "understand the strange cultures within the frame of their own style of living and to struggle not to approach them through one's own "cultural lenses"” (VON DER STEINEN 1894:65). Almost a hundred years later, Clifford Geertz commented: "One of the main methodological problems in writing about religion scientifically is to put aside at once the tone of the village atheist and that of the village preacher, as well as their more sophisticated equivalents, so that the social and psychological implications of particular religious beliefs can emerge in a clear and neutral light" (GEERTZ 1993:123). It is obvious that Frič indeed put on the "cultural lenses" of positivism and atheism, taking upon himself, in the words of Geertz, the role of the "village preacher" of the positive science. However, we can understand his efforts as signaling the beginning of an important transformation of the sciences of men; changes that influence anthropological theory and practice still today. He embodied the confusion and struggles of the period when anthropology definitively changed over from collecting to analysis, and at the same time opened its academic ivory tower and assumed distinctive social appeal.

\section{Bibliography}

AARNE, Antti - THOMPSON, Stith (1961): The Types of the Folktale: A Classification and Bibliography. Helsinki: Suomalainen Tiedeakatemia.

anon., "The Loan Collection of Objects used in Worship", Science 19:481 (22-IV-1892), pp. 225.

ARDAO, Arturo (1963): Assimilation and Transformation of Positivism in Latin America. In Journal of the History of ldeas 24:4, 515-522.

BAĎUROVÁ, Monika (2012): Ethnographic Collection of Alberto Vojtěch Frič in the Náprstek Museum. In Annals of the Náprstek Museum 33 (2012), pp. 5-50.

BALÍK, Stanislav et al. (2016): Der tschechische Antiklerikalismus: Quellen, Themen und Gestalt des tschechischen Antiklerikalismus in den Jahren 1848-1938. Wien: LIT Verlag.

BARTOŠEK, Theodor (1914): Co je Volná myšlenka [What is Free Thought]. Prague: Volná myšlenka, 1914.

BASTIAN, Adolph (1892): Wie das Volk denkt. Ein Beitrag zur Beantwortung socialer Fragen auf Grundlage ethnischer Elementargedanken in der Lehre vom Menschen. Berlin: Emil Felber. 
BRÄUNLEIN, Peter J. (2005): The Marburg Museum of Religions. In Material Religion: The Journal of Objects, Art and Belief 1:2, pp. 177-180.

COHEN, Gary B. (2006): The Politics of Survival: Germans in Prague, 1861-1914. West Lafayette, Ind.: Purdue University Press ( $1^{\text {st }}$ ed. 1981).

CUNO, James (2008): Who Owns Antiquity? Museums and the Battle over Our Ancient Heritage. Princeton: Princeton University Press.

DE LUCIA, Daniel Omar (1999): Laicismo y cientificismo en una gran capital. El Congreso Internacional de Libre Pensamiento. In Margarita Gutman, Thomas Ford Reese (eds.): Buenos Aires 1910. Buenos Aires: Eudeba, pp. 195-205.

DUNCAN, Carol (1995): Civilizing Rituals. New York: Routledge.

EHRENREICH, Paul (1905): Die Mythen und Legenden der südamerikanischen Urvölker und ihre Beziehungen zu denen Nordamerikas und der alten Welt. Berlin: Asher.

FERREIRA FRIČ, Rodolfo - FRIČ, Alberto Vojtěch (2012): Indiánská knížka [The Indian Book], ed. Yvonna Fričová. Prague: Titanic.

FILIPOVÁ, Marta (2011): Peasants on Display: The Czechoslavic Ethnographic Exhibition of 1895. In Journal of Design History 24:1, pp. 15-36.

FISCHER, Manuela - BOLZ, Peter - Kamel, Susan (eds.) (2007): Adolf Bastian and His Universal Archive of Humanity: The Origins of German Anthropology. Hildesheim: Georg Olms.

FRIČ, Vojtěch (1906a): Eine Pilcomayo-Reise in den Chaco Central. In Globus 89:15, pp. 229-234.

FRIČ, [Vojtěch] (1906b): I. Die Bilderschrift der Machikui-Indianer im Chaco Boreal, II. Mythen- und Menschenwanderungen in Südamerika. In Korrespondenz-Blatt der Deutschen Gesellschaft für Anthropologie 35:2, pp. 144-149.

FRIČ, Vojtěch (1907a): Sambaqui-Forschungen im Hafen von Antonina (Paraná). In Globus $91: 8$ (28-II), pp. 117-122.

FRIČ, Vojtěch (1907b): Misie a civilisace Indiánů [Missions and Civilization of Indians]. In Volná myšlenka, pp. 130-135.

FRIČ, Vojtěch (1912a): Resultado de mi último viaje al Chaco. In Actas del XVIII Congreso Internacional de Americanistas. Buenos Aires, pp. 473-475.

FRIČ, Vojtěch (1912b): Las religiones de los Indios de la Cuenca del Plata. In Actas del XVIII Congreso Internacional de Americanistas. Buenos Aires, pp. 476-486. 
FRIČ, Vojtěch (1912c): Význam vědy porovnávaných náboženství [Importance of the Study of Comparative Religions]. In Věk rozumu/Age of Reason (New York) 2:6, pp. 156-160 (cutting in ANpM, fund Frič 6/3).

FRIČ, Alberto Vojtěch (1912d): Londýn: Britické museum [London: British Museum]. In Středa, list čtrnáctidenní 1:13, pp. 326-329 (cutting in ANpM, fund Frič 6/1).

FRIČ, Alberto Vojtěch (1913): Onoenrgodi-Gott und Idole der Kad'uveo in Matto Grosso. In International Congress of Americanists, Proceedings of the XVIII. Session, London 1912, London: Harrison and Sons, Vol. 2, pp. 397-407.

FRIČ, Alberto Vojtěch (1918): Mezi indiány [Among Indians], Praha: A. Koníček.

FRIČ, Alberto Vojtěch (1977): Indiáni Jižní Ameriky [Indians of South America]. ed. Václav Šolc, Praha: Orbis ( $1^{\text {st }}$ ed. 1943).

FRIČ, A. Vojtěch - RADIN, Paul (1906): Contributions to the Study of the Bororo Indians. In Journal of the anthropological institute $36, \mathrm{pp} .382-406$.

GEERTZ, Clifford (1993): The Interpretation of Cultures: Selected Essays, London: Fontana Press (1st ed. 1973).

GINGRICH, André (2017): German-language Anthropology Traditions around 1900: Their Methodological Relevance for Ethnographers in Australia and beyond. In Nicolas Peterson, Anna Kenny (eds.): German Ethnography in Australia. Acton: ANU Press, pp. 29-54.

HANSEN, William (1997): Mythology and Folktale Typology: Chronicle of a Failed Scholarly Revolution. In Journal of Folklore Research 34:3, pp. 275-280.

HEGER, Franz (ed.) (1910): Verhandlungen des XVI Internationalen AmerikanistenKongresses. Wien/Leipzig: Hartleben.

HODAČ, Tomáš (2009): Dialektika divočiny a civilizace: způsoby konceptualizace a reprezentace indiánů $v$ díle Alberta Vojtěcha Friče [Dialectics of wildernes and civilization: conceptualizations and representations of Indians in the works of Alberto Vojtěch Frič]. Unpublished M.A. thesis, Charles University.

HOUŽVIČKA, Václav (2016): Czechs and Germans 1848-2004: The Sudeten Question and the Transformation of Central Europe. Praha: Karolinum.

HOZÁK, Jan (ed.) (1997): Národní technické museum. Historie-současnost-sbírky [National Technical Museum. History-Present-Collections]. Prague: NTM.

KANDERT, Josef (1983): Alberto Vojtěch Frič - On the Centenary of his Birth. In Annals of the Náprstek Museum 11, pp. 111-161. 
KLÁPŠŤOVÁ, KATEŘINA (2016): Dakotská kultura na rozcesti//Dakota Culture at the Crossroads. Prague: Národní museum.

KODYM, Stanislav (1955): Dům U Halánků: Vzpomínky na Vojtu Náprstka [The House U Halánků: Remembrances of Vojta Náprstek]. Prague: Československý spisovatel.

KUDLÁČ, Antonín K. K. (2005): Příběh(y) Volné myšlenky [Story(ies) of the Free Thought]. Prague: NLN.

KUHN, Thomas (1962): The Structure of Scientific Revolutions. Chicago: Chicago University Press.

LÉVY-BRUHL, Lucien (1926): How Natives Think. transl. Lilian A. Clare. London: George Allen \& Unwin (orig. French ed. 1910).

MAJER, Jiři (1994): Vojta Náprstek a počátky českého průmyslového muzejnictví [Vojta Náprstek and the Beginnings of the Czech Industrial Museum]. In Jan Hozák (ed.): Vojta Náprstek a muzejnictví [Vojta Náprstek and Museums]. Prague: NTM, pp. 15-21.

MINUCCIANI, Valeria (2013): Considerations in Relation to the Museography for Objects of a Religious Nature. In Valeria Minucciani (ed.): Religion and Museums: Immaterial and Material Heritage. Torino/London/New York: Umberto Allemandi \& C., pp. 11-23.

NEŠPOR, Zdeněk et al. (2010): Náboženství v 19. století: Nejcírkevnější století, nebo obdobi zrodu českého ateismu? [Religion in the $19^{\text {th }}$ Century: The Most Confessional Century, or the Time of the Birth of Czech Atheism?]. Prague: Scriptorium.

PÁNEK, Jaroslav - TŮMA, Oldrich et al. (2009): A History of the Czech Lands. Prague: Karolinum.

PENNY, Glenn (2002): Objects of Culture: Ethnology and Ethnographic Museums in Imperial Germany. Chapel Hill/London: The University of North Carolina Press.

PENNY, Glenn (2003): The Politics of Anthropology in the Age of Empire: German Colonists, Brazilian Indians, and the Case of Alberto Vojtěch Frič. In Comparative Studies in Society and History 45:2, pp. 249-280.

PENN, H. Glenn (2007): Transnational History in Historical Perspective: Bastian's Museum Project. In Manuela Fischer, Peter Bolz, Susan Kamel (eds.): Adolf Bastian and His Universal Archive of Humanity: The Origins of German Anthropology. Hildesheim: New York, pp. 50-54.

PINA-CABRAL, João de (2008): History of Anthropology and Personal Biography. In Anthropology Today, Vol. 24, No. 6, pp. 26-27 (review essay). 
PU゚TOVÁ, Barbora (2013): Moving beyond Borders: Vráz, Frič and Kořenský. In Národopisná revue 5, pp. 3-18.

REY, Marie-Catherine et al. (2001): National Museum Arts asiatiques - Guimet. Paris: Éditions de la Réunion des Musées Nationaux.

RODRIGUEZ, Julia (2013): Beyond Prejudice and Pride: The Human Sciences in Nineteenth- and Twentieth-Century Latin America. In Isis 104:4, pp. 807-817.

SALAZAR, Carles (2015): Introduction: Science, Religion and Forms of Life. In Carles Salazar, Joan Bestard (eds.): Religion and Science as Forms of Life: Anthropological Insights into Reason and Unreason. New York/Oxford: Berghahn Books, 2015, pp. 123.

SECKÁ, Milena (2011): Vojta Náprstek: Vlastenec, sběratel, mecenáš [Vojta Náprstek: Patriot, Collectioner, Maecenas]. Prague: Vyšehrad.

STOCKING, George (ed.) (1985): Objects and Others: Essays on Museums and Material Culture. Madison: University of Wisconsin Press.

STOCKING, George (ed.) (1991): Colonial Situations: Essays on the Contextualization of Ethnographic Knowledge. Madison: University of Wisconsin Press.

ŠÁMAL, Martin (2013): Emil Holub: Cestovatel - etnograf - sběratel [Emil Holub: Traveller - Ethnographer - Collector]. Praha: Vyšehrad.

TYLOR, Edward Burnett (1871): Primitive Culture. London: J. Murray, 2 vols.

VERMUELEN, Jan F. - ALVEREZ Roldán, Arturo (eds.) (1995): Fieldwork and Footnotes: Studies in the History of European Anthropology. London: Routledge.

WOLBERT, Johannes - SIMONEAU, Karin (eds.) (1987): Folk Literature of Chamacoco Indians. Los Angeles: University of California Press.

\section{Archival funds}

ANpM Archive of the Náprstek Museum, funds Frič, Náprstek, Hloucha, Scrapbooks.

AEÚAV Archive of the Institute for Ethnology of the Academy of Sciences of the Czech Republic, Ms. 445 